\title{
Assisting Pupils of Aduamoa D/A Junior High School Level 2 To Understand The Concept Of Water Purification Using The Filtration Method
}

Samuel Dontoh* Med. Millicent Bartels-Woode ${ }^{1}$ Dip.Daniel Amoah² Med Abudulai Kamilu-Mohammed ${ }^{3}$ Med $^{2}$

*1 2. Offinso College of Education, Offinso-Ashanti. Ghana W/A

3. Gambaga College of Education, Gambaga- Northern Region of Ghana W/A

\begin{abstract}
The purpose of the study was to develop strategies to aid pupils of Aduamoa D/A Junior High School level 2 to understand the concept of water purification using the filtration method. The population used for the study was 30 pupils and also the cluster sampling technique was used. The research instruments used to collect thee data were observation, tests in the form of pre-test and post-test, questionnaire and interview. The researcherused action research design for the study. Data collected from both pre-test and post-test were analyzed using simple percentages and frequency distribution tables and the study came out with the findings; The filtration method can be applied using participation activities that enhance pupils' understanding of the concept, and pupils'behaviour towards science improved remarkably after they were taken through the simple experimental procedure.
\end{abstract}

Keywords: Purification, Impurities and Filtration

DOI: $10.7176 / \mathrm{JEP} / 10-10-12$

Publication date: April $30^{\text {th }} 2019$

\section{Background to the Study}

Water is a basic necessity of life. We need water to drink, to wash our hands, to cook, for plants growth and for industrial purposes. Water is defined by the Longman Active Study dictionary of Contemporary as "a substance (of molecular formula $\mathrm{H} 2 \mathrm{O}$ ) found at room temperature and pressure as a clear liquid in rivers, lakes and seas its solid form is ice and its gaseous form is steam"

The Cambridge learner's Dictionary also defines water as "the clear liquid that falls from the sky as rain and can be found in seas, lakes and rivers. Clean water and sanitation considerably lesson water -related diseases which kill thousands of children everyday (UN, 2005). According to the World Health Organization (WHO), 1.1 billion people lacked access to an enhanced water supply in 2002, and 2.3 billion people got ill diseases caused by unhygienic water. Each year 1.8 million people die from diarrhea diseases, and $90 \%$ of these deaths are children under five years ( WHO, 2004). Our bodies use water in all its cells, organs and tissues to help regulate its temperature and maintain other bodily functions. Because our bodies lose water through breathing, sweating and digestion, it is important to rehydrate by drinking clean and impurities free water; at least eight glasses a day. That is why the United Nation Millennium Development goal VII is geared towards ensuring environmental sustainability and to help people get accessible and affordable safe drinking water.

According to Ghana water statistics (2019), close to six million people (nearly 22 percent) rely on surface water to meet their daily water needs, leaving them vulnerable to water-related illness and diseases. Sarver (January 10, 2013), "Every year 3.4 million people die from lack of accesses to fresh water globally" and this is a serious problem to be looked into. Since the 1960's the Ghana Water Company Limited (GWCL) has focused its activity in the urban areas at the expense of the rural areas (GWCL, 2007). According to the Ghana 2003 Core Welfare Indicators Questionnaire (GWIQ II) survey Report (GSS, 2005), roughly 97\% in Accra, 86\% in Kumasi and 94\% in Secondi-Takoradi owned pipe-borne water.

Human activities such as mining in water bodies, washing in water bodies, dissolved substances such as oxygen, nitrogen, andsulphates can also make water unsafe to use. Suspended materials such as living and dead organisms, soil particles, germs, domestic sewage and industrial waste are referred to as impurities. It is unfortunate that pupils of Aduamoa D/A J.H.S level 2 find it difficult to understand this concept considering the fact that the concept evolve around their everyday lives. Ampofo (March 2007). "Although the current water purification mechanism by Ghana water Company meets the WHO standards, it fails to clean hazardous planktons in Ghana's water sources". This study therefore seeks to find out why pupils of Aduamoa D/A J.H. S level 2 are unable to comprehend the concept of "purification of water" a sub-topic under "water". 


\section{Statement of the Problem}

During the researchers' study at Aduamoa D/A J.H.S, it came to light through classroom exercises that pupils in J.H.S level 2 could not answer questions on the concept which was taught by one of the researchers thrice within the week before assessing pupils. It was observed that about $80 \%$ of the class population scored below 4 out of the total marks which were 10. The researcher further used oral test to know whether pupils' difficulties were connected to expressing their ideas and thoughts in written form. Unfortunately, pupils could not define what impurities are, what is meant by water purification and how to purify water. The researchers then saw the need to investigate into this problem and develop relevant strategies to solve the problem of pupils' inability to understand the concept of "water purification".

\section{Purpose of the Study}

The project is purposely designed to;

- Investigate the factors responsible for students' inability to define water purification either orally or in written form.

- Develop appropriate learning strategies to solve the problem.

- Increase pupils' interest for science by engaging them in practical lessons.

\section{Research Questions}

The researchers constantly asked themselves certain indispensable questions concerning the problem in order for the researchers to efficiently recommend a remedy. Some of these questions included the following:

1. To what extent will the use of the filtration method help pupils to understand the concept of water purification?

2. How dowe increase and sustain pupils' interest for science?

3. How can science practical lessons be taught effectively?

\section{Significance of the Study}

The results of this research are expected to give contribution in some ways. The study will help J.H.S level 2 pupils of Aduamoa D/A pupils in all other junior high schools to develop interest in science as a subject. The researchers sought to inform and enlighten policy makers and practitioners on how to improve upon the use of filtration method of teaching water purification. This will also provide a medium of interaction between the researcher and the pupils to develop interest for science and to demystify the notion that science is a difficult subject. The findings in this document will be a vital reference that will provide guidelines for curriculum developers and stakeholders in our educational system. Again, it will help teachers to plan and deliver lessons effectively since pupils will be directly involved in science lessons through practical lessons.

\section{Factors Influencing Academic Achievement in Science as a Subject}

Various factors have been given for poor performance of students in science. Rothstein (2000) argues that learning is not only a product of formal schooling but also of communities' families and peers. Socioeconomic and socio-cultural forces can affect learning and thus school achievement.

\section{Home-Related Factors}

Whether a child performs well in school can be influenced by a range of household factors. These include socio-economic status (education, occupation and income), size of the household, type of discipline at home, family structure, and level of parental involvement and interest in child schooling are factors which affect performance precisely in science as a subject (Adane 2013 page 18). Engine-Demir (2009) argued that sizable research has consistently shown that students' poor academic achievements in science have been influenced by background of family characteristics such as socio-economic status of parents. Schiller, KhmelKov and Wang (2002) also argued that parents who have more education appear better able to provide their children with the academic and social support important for educational success when compared to parents with less educational background. Asikhia (2010) pupils from poor homes arte forced out of school and made to engage in hawking, selling packaged drinking water and the likes so as to save money for their school expenses. Adane (2013) as cited in Asikhia (2010) corroborate with the fact that since science is a technical subject, pupils' absence during instructional period can adversely affect their performance in the subject. Research work has shown that the 
nature of parental discipline affects academic output of children (Aremu, 2000). Oluwole (2001) found that the degree of self-efficacy and anxiety manifested by learners determine their academic performance. On the other hand, children from permissive homes are too complacent, unmotivated, and lack personal will to succeed. The democratic style of parenting has been found to be very helpful to teaching -learning situation. Aremu (2000) observes from a study that undergraduate that receive democratic type of parenting perform better than counterparts form autocratic homes. Houtenwille (2008) also argued that parental involvement has a strong positive effect on students' achievement. Thus parental style does not come to play in pupil's academic achievements.

\section{School -Related Factors}

Several school environmental factors have generally been identified as influencing academic performance. These include availability of instructional materials, school location and quality of the physical facilities, class size and pupil teacher ratios, teacher qualification and experience, and supervision. (Adane, 2016). Instructional materials provide information, organize the scope and sequence of the information presented, and provide opportunities for pupils to use what they learned. (Lockhead\&Verspoor, 1991). Students usually perform better when they have books or study aids to foster their learning. Fosuaa (2010 page 20) however believes that when science lessons are taught through practical's, it will help pupils to grasp concept without necessarily consulting other materials when they close from school. Posuaa, (2010) therefore, agrees with the Chinese proverb: "tell me I forget, show me I remember involve me I understand" will effectively help in the teaching of science.

\section{Participation and Performance in Science Education}

At the compulsory education (Basic Education), science education is compulsory. Therefore, a low participation for girls in science education at that level may be as result of a low enrollment number for girls in school or drop-out girls are entering into science and science-related subject areas which hitherto had been perceived as the preserve of boys for many years. The present challenge is how to motivate, increase and sustain the interest of girls in science education and this has become an issue of concern with Ghanaian educational system (Anderson, 2005 page 33). In most rural African societies, women interact with the environment more than men do in the realm of agriculture and the tapping of other natural resources for domestic uses; hence women become the primary users of science in daily living (Avotri et al, 2000). Yet, Harding and Parker (1995) found in their research that everywhere, women are poorly represented in areas of employment that require science related qualification, except biology and health related subjects like medicine and nursing. There are numerous studies confirming aspects of science than girls have, (see for example Clark, 1972; McGuffin, 1973 and Gardner 2001) with boys performing better than girls in most of the sciences (Avotri et al., 2000). An available data in general science, taken at BECE for the period of 1995 to 1997 show that, there are gender differences in performance in favour of bonus. The performance over the period in general science for boys and girls who obtained grades 1-66 are: in $1995,80.5 \%$ of boys as against $73.7 \%$ of girls, in $1996,76.3 \%$ and $69.2 \%$ of boys and girls respectively. Similar pattern is seen in 1997, but girls showed some improvement in performance, $78.2 \%$ of boys as against $75.3 \%$ (Avotri et al, 2000). Sjberg (2002) also confirms that from a gender perspective, biology in particular is more popular among girls; chemistry does not show a clear gender profile. On the other hand, physics which appears more mathematical is the most problematic for both boys and girls, but less among girls. Rutherford and Ahgren (1990) have argued that the content and practice of school science have not connected with pupils' interests and experiences, leading to a sense of its irrelevance of their lives. It can be argued that one consequence of this is that favourable attitudes towards and interest in science are probably eroded by in experienced science teachers.

\section{The Concept of Water}

Water, according to Symons et al (2000) is a transparent, odorless, tasteless compound of hydrogen and oxygen, $\mathrm{H}_{2} \mathrm{O}$. Water, in a more or less impure state, constitutes rain, oceans, lakes, rivers and other such surface water bodies as well as groundwater. Water, abundant natural resources, is critical for the sustenance of human life. Water occupies a central position in the basic needs of humans to the extent that it is next to oxygen in order of importance (Ogunnowo, 2004) literally then, water means life and prosperity. Water is a key determinant of sustain able development that should be carefully managed to make four suitable and sustainable human health and well-being. Ogunnowo, 2004).Fanira (1977) affirms what was cited in Ogunnowo (2004) that an assured supply of water both qualitatively and quantitatively for both domestic purposes (like drinking, 
bathing, cooking and general sanitation such as laundry and other household chores) and economic activities (like livestock and irrigation) greatly improves the social and economic activities of people. According to Oyebande (1986) any shortage or pollution of such a vital resources hinders growth and development.

\section{Economic Value of Water}

"In a market system, economic value of water, defined by its price, serves as a guide to allocate water among alternative uses, potentially directing water and its complementary resource's into uses in which they yield the greatest total economic return". (Ward and Michelsen, 2002). "The word value to be observed, has two different meanings and sometimes expresses the utility of some particular object and sometimes the power of purchasing other goods which the possession of that object conveys. One may be called value in use; the other, value in exchange. The things which have the greatest value in use have frequently little or no value in exchange on the contrary; those which have the greatest value in exchange have frequently little or no value in use". Darko (2016) "Nothing is more useful than water agreeing to what Adam Smith said. (Wealthof Nations-book I, chapter IV)

\section{Water Treatment}

Water treatment is any unit process that changes or alters the chemical, physical, and bacteriological quality of water with the purpose of making it safe for human consumption and appealing to the customer. The broader objective of water treatment operation is to provide potable water for consumption; however the basic goal is to protect public health (Darko, 2016 page 12).

\section{Filtration as a Method of purifying Water}

Darko (2016), water filtration process is the separation of large and unseats led particles from water by passage through a porous filtration media usually sand, granular coal, or granular activated carbon. However, Adane (2010) describes filtration as the process of separating suspended solid matter from a liquid, by causing the latter to pass through the pores of a membrane, called a filter. The liquid which is obtained after filtration is called the filtrate; in this case, water is the filtrate; in this ace, water is the filtrate. The filter can be a paper, cloth, cotton-wool, sand and any other porous material cited in Darko (2016 page 12). According to Adane (2010) filtration is best used in water treatment and sewage treatment. Symons et al (2000) argue that chlorine is an effective water purification method that kills germs, parasites and other disease-causing organism found in ground or tap water, whereas filtering is good for basic water tasks such as sediment and chlorine removal. The filtration method will go a long way to enhance pupils' understand because this method can be experimented in class since the teaching and learning materials can be improvised.

\section{Why Science Practical's are Important to Junior High Students}

Most practitioners would agree that good-quality practical work can engage students, help them to develop important skills, help them to understand the process of scientific investigation, and develop their understanding of concepts Woodley (2009 page 49). Millar (2004), a really effective practical activity enables students to build a bridge between what they can see and handle (hands-on) and scientific ideas that account for their observations (brains son). Making these connections is challenging, so practical activities that make these links explicit are more likely to be successful.

According to Woodley (2009 page 50) practical science supports:

1. Skill Development

- Planning

- Manipulation of equipment

- Observation

- Analyzing

2. The development of personal, learning and thinking skills (PLTs) and how science works (HSW)

3. Independent Learning

- Students work at their own pace

- Students work at their own level

- Supports differentiation by outcome, task and questioning

- Build students confidence 
4. Learning in Different ways

- Working in teams

- Working as individuals

- $\quad$ Observing using all senses

Millan (2009), practical work is a prominent and distinctive feature of science education. Many science teaching and others see practical work carried out by the students themselves as an essential element of good science teaching. As one teacher put it in an interview study (Donnelly, 1995), "it's what science is all about really...science is a practical subject". (page 97). How to teach science practical's effectively? According to Brenton (2016), science practical's can be effectively taught through the following ways:

1. Make them see it as part of their daily life

Try as hard as you can to find a way to relate the subject to their daily lives. It will make it much more likely for students to be invested in what you are explaining

2. Show the relevance to their future careers students think that, at the end of the day, they are at school so they can get ready to get good jobs in the future. This is how most of the people (parents included) see school nowadays, unfortunately. So the must take advantage of it, and try to relate your subject to how it can be applied in a work environment.

3. Let students participate in the practical process

If a teacher wants to see students really engaged about something, let students participate, and not only after distributing tasks but from the very beginning. Ask pupils for inputs on the activity, which resources will be used and how they will be evaluated.

4. Use multiple resources

To avoid students' sleeping during science practical's, the use of multi resources should be encouraged. Resources can be improvised to ensure that every pupil in class will perform the task from the beginning to the end. Noveri (2006), practical science activities have huge significance in the learning process. They engage pupils, helping them to develop important skills, understand the process of scientific investigation and develop a broad understanding of scientific concepts.

\section{Research Design}

The researcher used action research design for the study. Action research was adopted because the research is based on a case study of a problem which needs immediate solution in the classroom. Action research according to Waters-Adams (2012), is a practical approach to professional inquiry in any social situation. Relative to education, action research is relevant to teachers and their engagement with pupils in finding solutions to their educational problems that rise as they interact. Historically, the term action has been long associated with the work Lewin, who viewed this research methodology as cyclical, dynamic and collaborative in nature (Mills, 2013). Through repeated cycles of planning, observing, and reflecting, individuals and groups engaged in action research can implement changes required for educational improvement (Hine, 2013). The diagram below explains why action research is cyclical as cited by Mills (2013).

\section{Diagram 1.0}

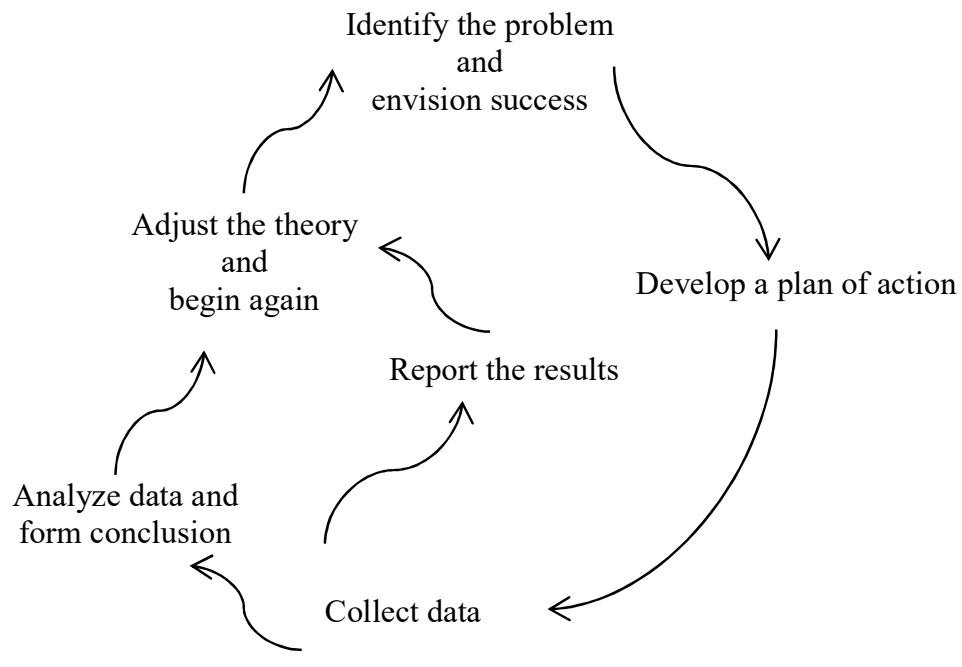


Action research is either research initiated to solve an immediate problem or a reflective process of progressive problem solving led by individuals working with others in teams or as part of a "community of practice" to improve the way the address issues and solve problems (wikipedia). Narri (2015), in schools, action research refers to a wide variety of evaluative, investigative, and analytical research methods designed to diagnose problems or weakness - whether organizational, academic, or instructional - and help educators develop practical solutions to address them quickly and efficiently.

Action research is important because:

(1) It provides the means by which professional people may increase the effectiveness of the work in which they are engaged in Stringer (2008).

(2) It enables researchers to develop a systematic, inquiring approach towards their own practices (Frabutt et al., 2008).

(3) It helps practitioners to develop new knowledge directly related to the classroom (Hensen, 1006).

(4) Teachers are empowered when they are able to collect their own data to use in making decisions about their schools and classroom. (Zeichner and Noftke, 2001).

(5) It is an effective and worthwhile means of professional growth and development Osterman (1993).

In short, action research can be defined as an approach in which the researcher and pupils collaborate to diagnose a problem and develop solutions based on the diagnosis.

\section{Diagram 1.1}

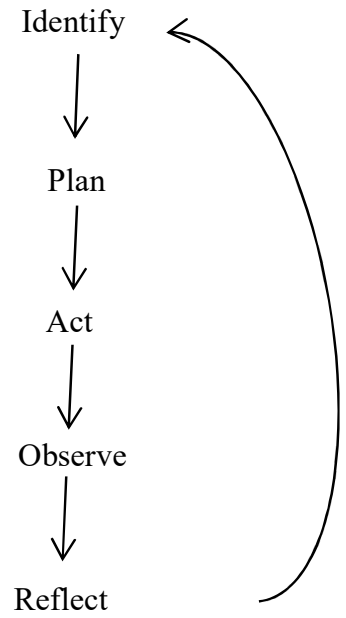

Despite the numerous advantages of action research, it has the following setbacks.

(1) Delays in completion of action research thereby taken a period of time to solve an identified problem (Harrine, 2012).

(2) Lack of rigor and originality

(3) Results are not generalizable

\section{Setting}

The research was conducted in a school in Aduamoa, a small town in Afigya Kwabere district. Aduamoa D/A J.H.S was established to meet the educational needs of the people in the Aduamoa township. The school has about 102 student population. Out of the total population, 52 are boys and 50 are girls. The school has 2 female teachers and 6 male teachers and a head teacher. 


\section{Target population}

www.Vocabulary.com (2015) defines population as the number of people in a geographical area. Population is an essential tool for research work. The target population for the research work was all Basic Schools in Afigya Kwabere in the Ashanti region, Ghana.

\section{Accessible population}

The accessible population is the population in research to which the researcher can apply her conclusions. This population is a subset of the target population. The accessible population for the study was all basic pupils in the junior high school of Aduamoa D/A school as shown below:

Table 1.0: Population of J.H.S pupils in Aduamoa D/A

\begin{tabular}{lll}
\hline Class Total & Male accessible populace & Female accessible populace \\
\hline J.H.S 1 & 13 & 15 \\
28 & 20 & 12 \\
J.H.S 2 & & \\
32 & 19 & 23 \\
J.H.S 3 & & \\
42 & $\mathbf{1 0 2}$ & $\mathbf{5 0}$ \\
Total & & \\
\hline
\end{tabular}

Source: Field data, 2019

\section{Sample Population}

A sample population is a smaller group of members of a population selected to represent the population. The sample population used for the study was J.H.S 2 pupils of Aduamoa D/A school. The total number of pupils in the class is 32 , consisting twelve (12) girls and twenty boys (20) with an average of 13 years $\left(13^{+}\right)$. Due to the huge number of the pupils of the class, the researcher decided to use part of the whole for the study precisely a probability sampling technique.

\section{Sampling Technique}

The researchers used cluster sampling where they divided the pupils into groups (clusters) and obtained a simple random sample of manageable pupils through the use of in or out on folded pieces of papers. Pupils were called to pick a piece of folded sheet from a bowl. Those who picked in were used for the study. This allowed the research instrument to be sufficiently tested.

\section{Research Instruments}

Research instruments or tools talk about how data will be collected using research tools. Research instruments include

- Questionnaire

- Interview

- Test

- Observation

- Checklist

- Autobiography

The researchers used questionnaire, interview, test and observation to collect data for the research work. How the instruments were used is described below. 


\section{Test}

Google web (2015) describes a test as a procedure intended to establish the quality, performance, or reliability of something, especially before it is taken into widespread use.

A test is an assessment intended to measure a testees' knowledge, skill, and aptitude, physical and intellectual fitness. A test may be administered verbally, on paper, or in a predetermined area that requires a testee to demonstrate or perform a set of skills (wikipedia). According to the Cambridge Dictionary, a test is a way of discovering, by questions or what someone or something can do or is like. Amiradu (2015) says testing is important in a school because it helps teachers and pupils to determine how much they have taught and learnt, respectively. It is because of the teacher trying to find areas of difficulty in order to take corrective measures that test are administered in schools. Test is an instruments used to measure the strengths and weakness of a person by assigning numerical figures to score.

In this research, the researcher used test to diagnose pupils' inability to comprehend the concept of water purification. It is also to find the effectiveness of a design in the intervention. The researcher finds test to be the most appropriate instrument for this research since it will measure pupils' ability effectively. Also, the test is easy to conduct and administrate. Moreover, test provides pupils responses individually which enables the researcher to obtain information based on the problem.

\section{Questionnaire}

Questionnaire is a research instrument consisting of a series of questions for the purpose of gathering information from responds. The Cambridge Learner's Dictionary explains questionnaire as a set of questions asked of a large number of people number of people to discover information about a subject. According to Debois (2016) a questionnaire is an instrument for collecting data and almost always involves asking a given subject to respond to a set of oral or written questions. Questionnaire is a suitable research tool because:

(a) It is quick and easy to collect results.

(b) Questionnaires are also a practical way to gather data.

(c) Questionnaire offer a way to gather vast amounts of data on any subject.

(d) It covers all aspect of a topic.

(e) Questionnaire ensures user anonymity. Respondents' answers are concealed thereby encouraging them to answer truthfully Debois (2016).

The questionnaire was used to find the cause of pupils' inability to comprehend the concept of water purification. The instrument was solely close ended and direct questions. In order to ensure reliability and validity of respondents response the researcher, in collaboration with other teachers explained the questions for the comprehension of the questionnaire. The reasons for the use of questionnaire was that the instrument can be completed at the respondents own convince.

\section{Observation}

It is a technique of collecting data that employs vision as the main means of data collection. In observation, researchers collect data on the current status of the subjects by watching them, listening to them and recording what they observed rather than asking questions about them. Observation allows the researcher to actually witness social behaviours in its natural settings.

DeFranzo (2014), observation is a systematic, direct, definite and deliberate examination of spontaneous occurrences at the time of their occurrence. Robertson (2013) also describes observation as an intensive examination of a particular group, event, or social process. The researcher does not attempt to influence what happens in any way but aims instead at an accurate description and analysis of what takes place. According to the Oxford Concise Dictionary, observation means 'accurate watching, noting the phenomenon by which they occur in the nature with regard to the cause and effect of mutual relations'.

Science begins with observation and the end also uses observation for the final validation - so it can be said that observation acts as a very elegant method in case of scientific investigation. In short, observation consists of the application of our mind and its cognitive powers to the phenomena which the researcher is studying. Hence, it 
can be said that observation acts a fundamental and the basic method of getting information about a subject. The researchers observed pupils for this research because

- It affords the first-hand information about pupils' performance.

- Worsley (2002) points out, "the peculiar strength of participant observation demands not complete detachment, but the involvement of the researcher in the lives of the people he is study... This gives him a deeper insight into the behaviour of the people he is studying".

\section{Data Collection Procedure}

This part of the study highlights the techniques that were used in the collection of data. Within the techniques, activities are planned implemented and monitored for a period of time. The techniques used in collecting data included step-by-step procedures that are constantly monitored. These procedures are of three phases. They are: Pre-intervention stage, intervention stage and post intervention stage.

\section{Pre-Intervention}

This is a serious activity or a procedure the researcher adopted in trying to define or diagnose the perceived problem before the actual intervention. Here, the researcher may do it alone or with a colleague who has knowledge in the problem. During the pre-intervention, the researcher may adopt any of the following or combine them to come out with the problem.

The use of instruments such as tasks, observations, questionnaires and so on. All these may help in diagnosing the problem which much certainly suggests an intervention. For the pre-intervention, test as data collection instrument was used to diagnose the extent of difficulties and also determine the effectiveness of the intervention program.

\section{Interventions}

The main intervention for the study is the use of filtration method to assist pupils overcomes their inabilities to answer questions based on the concept of water. To effective the goal of this study, pupils were asked to bring some materials to class. The intervention was implemented within two weeks. The implementation of the research was done during class hours on Monday and Thursday each week, from 8:00am to 9:00am each day. The filtration method was practically performed by each pupil.

\section{Description of the Filtration Method}

Filtration is used to separate a liquid from insoluble solid particles in a mixture. A mixture of water and sand can be used to purify water. The mixture or unpurified water is poured into a funnel, which has filter paper or cotton wool in it. The water drains through the filter paper or the cotton wool and funnel into a receiver leaving behind the same particles in the funnel. The insoluble solids obtain after filtration are called residue, while the liquid obtained after filtration is called the filtrate.

\section{Diagram 1.2}

Mixture of water and Sand
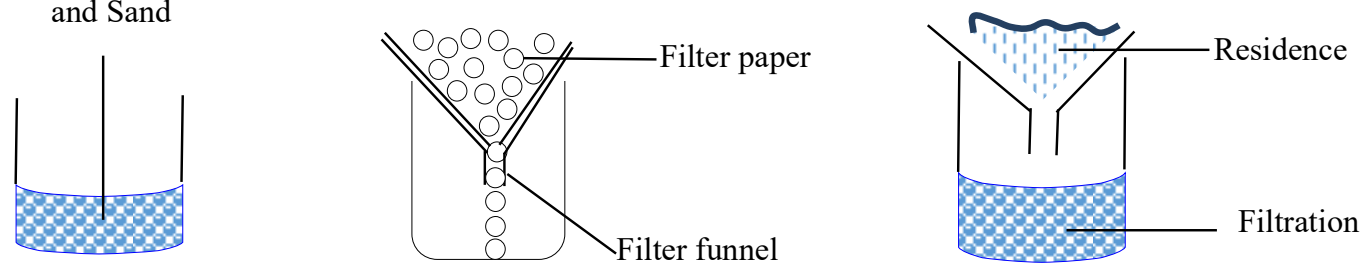

To get more purified water, the experimental process of diagram 1.3 was performed. 


\section{Diagram 1.3}

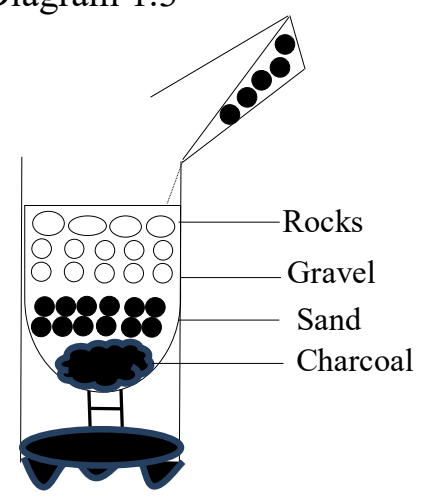

Materials used

- Bottles of mineral water

- Cotton wool

- Filter paper

- Charcoal

- Sand

- Gravel

- Rocks

- Water mixed with sand

- Cup

How the water receiver was constructed. Bottle of the mineral water was cut into two halves. The bottom half was used by the researcher as weather receiver and the top half also served as a funnel for the experiment.

\section{How the experiment was used to solve the problem}

All 32 pupils in the class had two halves of a bottle, a cup containing water mixed with sand, a piece of cotton wool and a filter paper. The researcher asked pupils to pour the water mixed with sand into their improvised funnel which had the filter paper and the cotton wool. Pupils were guided by researcher to collect the water using the bottom half of the bottle which served as a beaker for the experiment. The research assisted pupils to record their observation. The researcher repeated the experiment with pupils three times within the two weeks. Few pupils had difficulties during the first week. The researcher addressed pupils' individual challenges and encouraged them to redo the activity.

\section{Post test}

Pupils were tasked to define the process of the experiment (filtration). The researcher also asked pupils to explain some terminologies in relation to the experiment. Pupils responses were collected after the last meeting within the second week.

\section{Data Collection Procedure}

Class tests were collected progressively as interventions were implemented. The data collected included

- Ability to define water purification.

- Ability to explain filtration as a method of purifying water. 
- Ability to demonstrate how water can be purified.

\section{Method and Data Analysis}

Data collected was analyzed using simple percentages, frequency table and graphs. The performance of the pupils was graded accordingly as:

Below average - 0 - 9

Average - $10-14$

Above average - 15 - 20

Research question 1

To what extent will the use of the filtrations method help pupils to understand the concept of water purification?

Table 1:Response from teachers on how the filtration method will help pupils to understand the concept of water purification.

\begin{tabular}{lcc}
\hline Item & No of Respondent & Percentage \% \\
\hline Qualification of teachers & 4 & 12.5 \\
Use of TLM & 3 & 9.4 \\
Reinforcement & 4 & 12.5 \\
Regularity & 3 & 9.4 \\
Punctuality & 7 & 21.9 \\
Methods of teaching & 5 & 15.6 \\
Teaching with inferred notes & 6 & 18.7 \\
Total & $\mathbf{3 2}$ & $\mathbf{1 0 0}$
\end{tabular}

Sources: Field study 2019

From the table above table, three teach and relevant teaching and learning materials (TLM) to teach the concept of water purifications. This indicates clearly that few teachers use teaching and learning materials during instructional period. Considering the law percentage (that is $9.4 \%$ out of $100 \%$ ) of the involvement of TLM, pupils are not able to see, demonstrate and relate to the concept to facilitate understanding. Adane (2013) suggested that instructional materials provide information, organize the scope and sequence of the information presented and provide opportunities for pupils to use what they have learned.

The availability and use of TLMs off act the effectiveness of a teacher's lesson because teacher's presentation follows sequentially when it is supported with relevant teaching materials teaching and learning materials also ensure pupils maximum participation throughout the instructional period. This is because pupils maximum participation throughout the instructional period. This because pupils are able to see, interacts and manipulates materials for higher academic output. Thus teaching and learning, materials go a long way to enhance pupils understanding of the concept of water purification.

Also, the table indicates that the level and qualification of teachers at the researcher's field is low. Four teachers representing $12.5 \%$ are qualified teachers. Teachers'qualification affects learning process because teaching involves a more knowledgeable person in particular subject. The higher the qualification of the teachers, the better their efficiency. Teacher's qualification can be seen in the manner he asked questions, how to handle pupils' responses and how to manage classroom activities. Adane (2013) stressed that good seating arrangements which is a skill of a qualified teacher produce high academic achievement and performance while dilapidated buildings that lack mental stimulating facilities coupled with low or no seating arrangement is destructive. Qualification of teachers can affect the methodologies used during lesson delivery. 
Table 2: Head teacher and his assistant responses on the causes of pupils' inability to understand the concept of water purification.

\begin{tabular}{lcc}
\hline Item & Respondent & Percentage \% \\
\hline Poor method of teaching & 8 & 25 \\
In service training & 5 & 15.6 \\
Supervision on teachers & 5 & 15.6 \\
Textbooks & 4 & 12.5 \\
Classrooms & 6 & 18.8 \\
Teachers punctuality and regularity & 4 & 12.5 \\
Total & $\mathbf{3 2}$ & $\mathbf{1 0 0}$ \\
\hline
\end{tabular}

Sources: Field study 2019

As shown in table 8 respondent out of thirty-two respondents representing $25 \%$ pointed out on poor method of teaching. This indicates that, the method of teaching and strategies at the concept has become a major cause of pupils inability to understand the concept of water purification.

The table also indicates that 4 respondents out of the thirty-two respondents representing $12.5 \%$ pointed to inadequate textbooks. This affirms what was cited by Adane (2013) that pupils usually perform better when they have books or study aids to foster their learning. Pupils will be able to add more knowledge to what was taught when they go home.

Out of the thirty -two respondents 6 representing $18.8 \%$ pointed to classroom; which depicts that classroom adequacy affect pupils understanding of the concept of water purification classroom comfort, amount of light and the condition of the classroom can adversely affect academic work. As cited by Haribson and Hanushek (1992) that the quality of physical facilities is positively related to student performance. Adane (2018) also suggested that good seating arrangement and good buildings produce high academic achievements and performance, while dilapidated buildings that lack mental stimulating facilities coupled with low or no seating arrangement is destructive. Therefore, an enabling classroom conditions positively affect school performances.

\section{Research Question 2}

How do we increase and sustain pupils' interest for science?

Table 3: Teachers' responses on sustaining pupils' interest in science lessons.

\begin{tabular}{lcc}
\hline Item & Respondent & Percentage \% \\
\hline Good teaching methods & 5 & 15.5 \\
Adequate TLMs & 4 & 12.5 \\
Motivation & 6 & 18.8 \\
Punctuality to school & 6 & 18.8 \\
Giving exercise & 8 & 25 \\
Inadequate time & 3 & 9.4 \\
Total & $\mathbf{3 2}$ & $\mathbf{1 0 0}$ \\
\hline
\end{tabular}

Sources: Field study

From the table 3: it explains the method and strategies to be adopted to help pupils solve the problem of water purification. Four respondents out of thirty -two representing 12.5\% use adequate teaching and learning materials which is one of the strategies teachers can adopt to help overcome the problem. This support the saying that. 'I hear and forget, I see and remember Brenton's (2016) suggestion was very clear in the sense that if teachers wants to see pupils really engaged in a lesson, tasks should be distributed to pupils from the very beginning of the lesson. Since the percentage that corresponds with adequate TLMs is low pupils are not motivated to cultivate interest in science less. There are no available materials for pupils to manipulate hence the problem of understanding the concept. Woodely (2009) suggested that practical science supports.

1. Skill development

- Planning 
- Observation

- Evaluation

- $\quad$ analyzing

2. Independent learning

- Students work at their own pace

- Students work at their own level

- Builds student confidence

The above tale also shows that out of thirty-two (32) respondents, 3 representing $25 \%$ points to giving exercise $25 \%$ is low hence pupils poor attitudes towards the subject.

Table 4: Responses of parents on the causes of pupils' poor attitudes towards science

\begin{tabular}{lcc}
\hline Item & Respondent & Percentage \% \\
\hline Teachers level of education & 8 & 25 \\
Inadequate materials & 5 & 15.6 \\
Motivations & 4 & 12.5 \\
Poor method of teaching & 8 & 25 \\
Inadequate time & 7 & 21.9 \\
Total & $\mathbf{3 2}$ & $\mathbf{1 0 0}$ \\
\hline
\end{tabular}

Sources: Field study 2019

As shown in table 4, 8 respondents of thirty-two showed teachers level of education which represents $25 \%$. This is a clear indication that the level of education of teachers at the researcher's field of study is marginal hence pupils encounter problems with teachers' strategies and mythologies towards science lessons discouraging them from developing positive attitudes towards science. Five pointed out inadequate materials, out of the thirtytwo pupils representing $15.6 \%$. Four respondents representing $12.5 \%$ talked about motivation. Again 8 respondents out of thirty - two indicate poor method of teaching. The above information shows method and strategies of which the concept is taught has become a major problem and also killing pupils interest for the subject. Narri (2006) recommend training pupils by making teaching lively.

Practical and enjoyable lesson can be achieved by making sure that games, experiments and illustrations are the center line of the subject in question. It pupils are involved in the teaching and learning process and teachers address on the use of appropriate method, there would not be problem of understanding water purification.

\section{Research question 3}

How can science practical lessons are taught effectively. Table 5: Interview guide for parents on how effectively science lessons can be taught.

\begin{tabular}{lcc}
\hline Item & No of respondent & Percentage \% \\
\hline Punctuality in school & 6 & 18.8 \\
Parents assistance & 4 & 12.5 \\
Classroom motivation & 6 & 18.8 \\
Assignment & 8 & 25 \\
Inadequate time & 3 & 25 \\
Inadequate time & 3 & 9.4 \\
Teachers' bad method of teaching & 5 & 15.5 \\
Total & $\mathbf{3 2}$ & $\mathbf{1 0 0}$ \\
\hline
\end{tabular}

Sources: Field study 2019 
From the table 5, 4 respondents out of thirty-two representing $12.5 \%$ points to parents' assistance. This feedback shows that few parents are involved and concerned about their wards academics. Parents' attitudes towards pupils' academics is discouraging hence pupils find it difficult to excel academically. This is in agreement to what was said by Engin- Demir (2009) that sizable research has consistently shown that students' academic achievement has been influenced by background of family characteristics such as socio-economic status of parents. This suggest that parents who have more education appear better able to provide their children with the academic and social support important for educational success when compared to parents with less educational background.

Avotri et al (1999) also added that educational status of parents was a major factor determining a child's academic achievements. The table also indicates that 6 respondents out of thirty -two pointing to $18.8 \%$ shows punctuality in school. Pupils' irregular pattern of coming to school makes it difficult for them to overcome the problem understudy pupils do not come to school often making it difficult for them to understand what has been taught previously.

Again, out of the thirty-two total respondent, 6 representing $18.8 \%$ pointed out to classroom motivation. This shows how a teacher employs his/her teacher- learner activities to execute his lesson. These activities will either help sustain or decline pupils interest for the lesson. Eight respondents out of the thirty-two representing $25 \%$ points to assignment while 3 out of the thirty-two representing $9.4 \%$ pointed out to inadequate time. Five respondents which is equivalent to $15.5 \%$ also pointed out to teachers bad method of teaching. Brenton (2016) suggested six (6) ways to effectively teach science lessons.

- Make pupils see the subject as part of their daily life. This is done by creating an enabling atmosphere for pupils to relate the subject to their daily lives.

- Make it fun science should be demystified through the use of demonstrations, experiments and illustrations other than lecturing.

- Show the relevance to their future careers

- $\quad$ Let pupils participate in the whole process activities should mainly be pupils-centered thus distributing tasks for pupils from the very beginning of the lesson.

- The use of multiple resources. Resources should vary so that at least pupils use all their senses to learn.

- $\quad$ Understand pupils interest

Table 6

Pre-test

Frequency distribution table of marks of ten test items obtained by 32 pupils.

\begin{tabular}{|c|c|c|}
\hline Marks(x) & Frequency (f) & $\mathbf{F x}$ \\
\hline $\mathbf{0}$ & 11 & 0 \\
\hline 1 & 8 & 8 \\
\hline 2 & 1 & 2 \\
\hline 3 & 1 & 3 \\
\hline 4 & 3 & 12 \\
\hline 5 & 0 & 0 \\
\hline 6 & 2 & 12 \\
\hline 7 & 3 & 21 \\
\hline 8 & 2 & 16 \\
\hline 9 & 0 & 0 \\
\hline \multirow[t]{2}{*}{10} & 1 & 10 \\
\hline & $\varepsilon f=32$ & $\varepsilon f x=84$ \\
\hline
\end{tabular}

A simple bar graph showing the scores of pupils in the pre-test. 


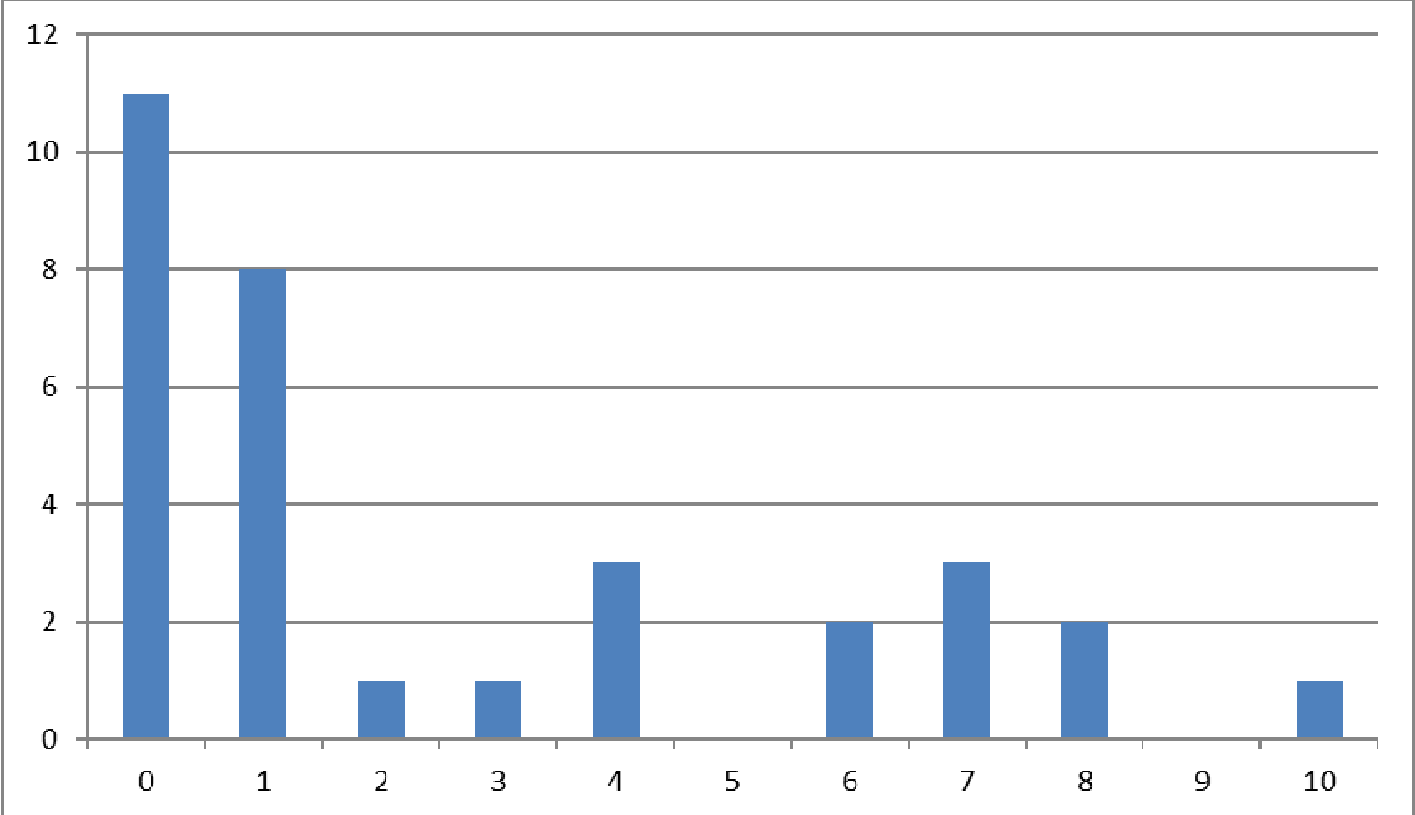

From table $6, \mathrm{cf}=32, \quad \mathrm{cfx}=84$

Mean $(\bar{x})=\frac{\text { off }}{r=T}$

$\rightarrow \frac{34}{32}=2.52$

From the above table, it is clear that eleven pupils could not answer questions on the concept water purification. Eight pupils go one pupils each scored 2 and 3 out of 10,3 pupils scored 4 and nobody had five test items correct. Two and three pupils scored 6 and 7 respectively. Two pupils scored ten out of ten. None of the pupils scored 9 out of 10 . In conclusion, pupils performed poorly.

Table 7Frequency distribution table of marks obtained by pupils in the post test.

\begin{tabular}{lcc}
\hline Marks(x) & Frequency (f) & Fx \\
\hline $\mathbf{1}$ & 0 & 0 \\
$\mathbf{2}$ & 0 & 0 \\
$\mathbf{3}$ & 0 & 4 \\
$\mathbf{4}$ & 1 & 10 \\
$\mathbf{5}$ & 2 & 36 \\
$\mathbf{6}$ & 6 & 49 \\
$\mathbf{7}$ & 6 & 64 \\
$\mathbf{8}$ & 7 & 27 \\
$\mathbf{9}$ & 8 & 50 \\
\hline
\end{tabular}




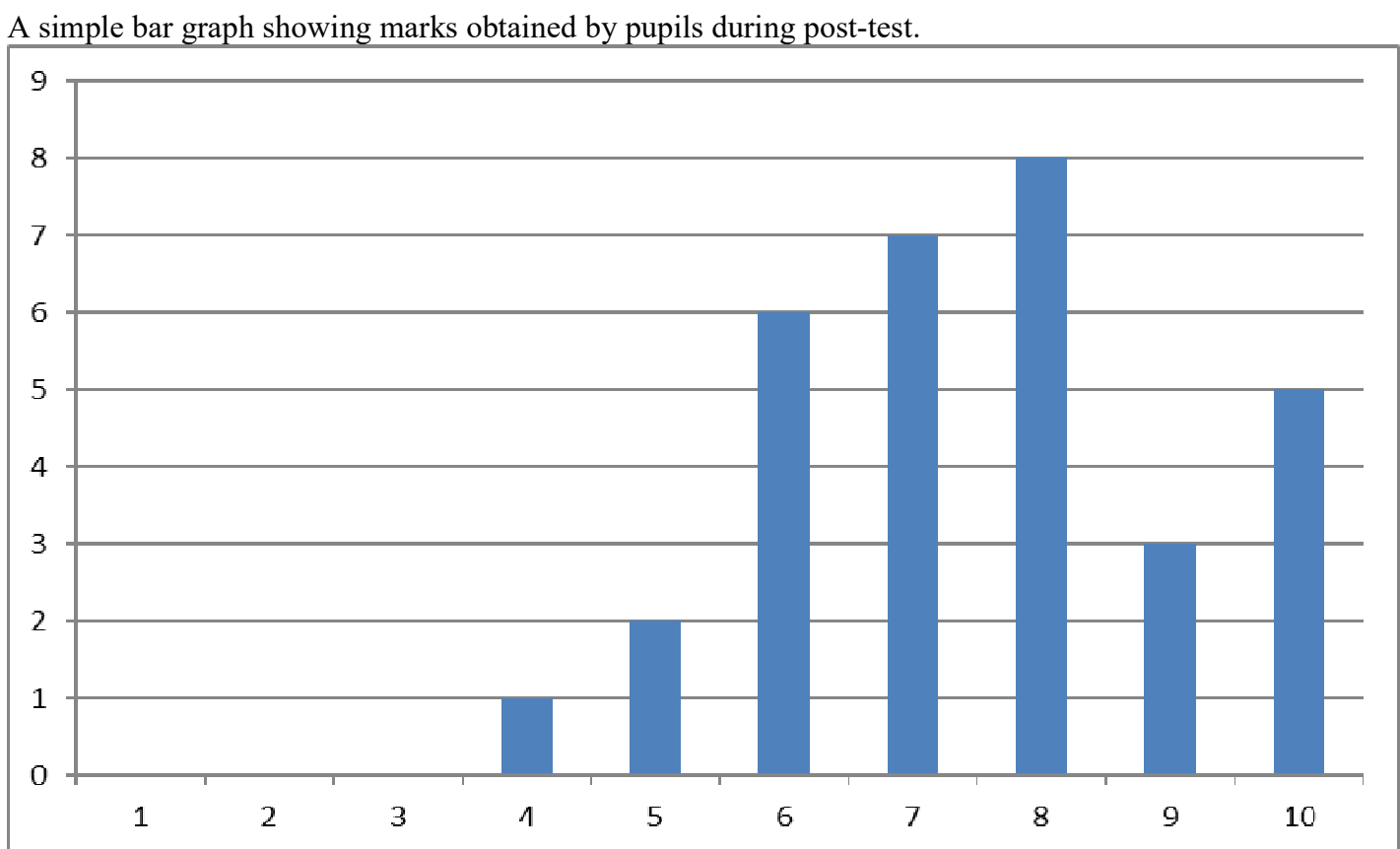

Marks (x)

From tables 7

Mean $(x)=\frac{e f x}{s f}$

$\rightarrow \frac{240}{32}$

$=7.5$

The above table shows that, one (1) pupil scored 4 out of ten (10). Two pupils scored 5, six (6) pupils had six (6) test items correct while eight (8) pupils also scored 8 out of ten 3 and 5 pupils scored 9 and 10 respectively.

To conclude, it shows clearly that pupils performed better during the post- test pupils average score increased from 2.62 to 7.5 . This was achieved through the use of filtration to teach the concept of water purification.

\section{Summary}

This action research was carried out of ADUAMOA D/A JHS 2. The researcher discovered the problem of pupils' inability to answer questions on water purification. The problem was specially discovered during a science class. The researcher real used that not even a fragment of the researchers' first lessons objective was achieved.The researcher took this problem as a challenge and sort of task which she must face and deal with the researcher spells out the various aspects of the problems and formulated research questions in an attempt to remedy the situation. It was such questions that led the researcher to draw plans develop strategies, adopt measures methods and instruments to rescue the situation. The researcher used test, questionnaire and interview to collect data for this study. In addition to the major instruments, the researcher conducted observation in the town (Aduamoa), on the pupils and combed through few school records to confirm some findings and serve as merits.

The researcher again discovered that inadequate and effective use of instructional time, truancy and attitudes of the pupils and lack of parental support were the causes of the pupils inability to understand the concept of water purification after a diagnostic test, the researcher adopted and developed the filtration method to aid pupils understand the concept.

\section{Conclusion}

This research study was an attempt to solve pupils' difficulties in understanding water purification. It was evidence in the table recording and figures that the problem really existed.

After intervention was implemented it was discovered that the pupils were able to answer questions based on the concept. These therefore, suggest that the researchers' interventions were effective, credible and valid in equipping the pupils to understand and answer questions based on the concept. 
Recommendation

The researcher therefore suggests;

- Those future researchers should use this material as one of the reference. They should also improve upon the techniques and the teaching and materials used in this project.

- $\quad$ That more than one instrument should to be used to collect data on the students

- That other aspect of the problem exists and should be investigate and dealt with.

\section{References}

Abomah P.W (2006). Introduction to Measurement and Evaluation and Research Methods in Education for Diploma and Undergraduate Students (Unpublished).

Akanle, O. B. (2007). Socio-Economic Factors Influencing Students Academic Performance in Nigeria.Some Explanation from a Local Survey.Sociology and Social Work Community. Retrieved

Aremu, A.O (2000), Academic Performance 5 Factor Inventory. Ibadan: Stiriling-Horden Publishers. Retrieved December 8, 2011, from http://www.eurojournal:comlejss

Arms, K. (2008)Environmental Science.Texas Holt, Rinchartand Winston: A Harcourt Education Company

Asamoah J. K et al (2003). Handbook on Teaching of Science in Senior High Schools. Ghana Education Service, Accra Ghana.

Barnes, W. (2003).Teachers' Participation in Community Development Activities in Ghana. Unpublished MPhil thesis, Brighton: University of Sussex

Cross, M. (2012), Science Concepts Young Children Learn Through Water Play. Lehman College, New York

Darlington, H. (2015) Increasing Students' Interests in Science Its Contribution of Practical Work. School Science Review 93(345), 105111.

Dompreh J.D.K (2002). Guidelines for Writing Project Work for Teaching Trainees.Jasikan College of Education (Unpublished)

Downey, D.B (1995). Bigger is Not Better: Family Size, Parental Resources, and Children's Educational Performance.American Sociological Review, 60, 746-761

February 4, from http://www.,edwelljo urnals.com/fulltextlpjss/2008/317-325.pdf

Fox, M. (2005). Science practicals for studentsGuidelines for Preparation of Action Research Project Work in Diploma Awarding.Teacher Training Colleges, Institute of Education, University of Cape Coast(Unpublished)

Harris and Sipay (1985). How to Increase Pupils Interest in Science? ( $2^{\text {nd }}$ Ed.) New York.

Hassan, M. M. (2002). Academic satisfaction and approaches to learning among Arab Emirate University pupils. Social Behaviour and Personality: An International Journal, 30, 443-451

Lewin-Benham, A. (2011). Twelve Best Practices for Early Childhood Education. New York, N.T: Teachers College

McLean, R. (1997). Selected Attitudinal Factors Related to Students' Success in High School. Alberta Journal of Educational Research, 43, 165 - 168

McNeal, R. B (1999). Parental Involvement as Social Capital: Deferential Affectiveness on Science, Achievement, Truancy and Dropping -Out Social Forces, 78, 117-144

Ministry of Education, Science and Sports (MOESS) (2007).Access to Basic Education in Ghana: The Evidence and the Issues. Brighton: Centre for International Education University of Sussex

Ogunnowo, C.O. (2004) Coping with Domestic Water Supply Problems in Nigeria Urban Centres. The Ijebu-Ode City Experience.International Journal of Issues, Pg.201-205.

Rothstein, R. (2000). Finance fungibility: Investing Relative Impacts in Schools And Non-School Educational Institutions to Improve Students Achievement. Centre on Educational Policy Publication. Washington, DC

Schiller, K. S., Khmelkov, V. T \& Wang, X. Q. (2002). Economic Development and The Effect of Family Characteristics on Mathematics. Journal of Marriage and Family 64, 730 -742

Smith.A. (1776).Wealth of Nations. London: W.Strahan and T. Cadell.

United Nations (2006).The Millemum Development Goals Report: United Nations Development Prgramme. Retrieved June 11, 2012, from www.UNDP.ORG/PUBLICATIONS/MDGREPORT2006.PDF

Gay, L.R. (1996). Educational Research Competencies for Analysis and Application Upper Saddle River, NJ.Prentice Hall, Inc.

Ghana Statistical Service (ass) . (2005) Core Welfare Indicators Questionnaire (CWIQ II) Survey Report: Statistical abstract GSS, Accra. (CWIQII) - 2003, V2.0

Gottfried, A.E. (1994). Role of Parental Motivational Practices In Children's Academic Intrinsic Motivation and Achievement. Journal of Education Psychology 86, 104-113. 
Hine, G. S. (2003) TheImportance of Action Research in Reacher Education Programs. Issues in Educational Research, 23(2) 15-163http//www.ur.org Gullier 231 line html.

Osterman, K. F\&KottKamp, R. B (1993)Reflective Practice for Educators Improving Schooling Through Professional Development: Newbury Bark, CA: Corwin.

Mills, G. E . (2011) Action Research: A guide for The Teacher Researcher( $4^{\text {th }}$ ed.) Boston;Pearson.

Wang, J., B. Wildman, L. (1995). An empirical Examination of The Effects of Family Commitment in Education on Student Achievement in Seventh Grade Science Journal of Research on Science Teaching 32, 833-857

Ward, F. A \& M. A( 2002) The Economic Value of Water in Agriculture : Concepts and Policy Applications Pg. 423-446

Waters- Adams, S (2006), Action Research in Education. Plymouth :University of Plymouth.

WHO (2004) WHO Guidelines for Drinking Water Quality, ( ${ }^{\text {rd }}$ ed.)Volume 1.Recommendations World Health OrganizationGeneva.

Zeichner, K.M. (2013) Teacher Research as Professional Development for P-12 Educators in the USA. Educational Action Research, 11(2), 301-326. http:11dx.doi.org/10.1080/0965079030020011 